\title{
The Theory of the Pleadings in Code States
}

\section{The Situation at Common Law.}

\section{A}

T COMMON LAW a party desiring to vindicate some legal right was required to diagnose his case, and state, not the facts of the particular transaction, but what he conceived the legal effect of those facts to be. A particular form of action was then adopted and at the trial the litigation was not merely concerning the substantive merits of the party's case, but also whether he had been correct in the diagnosis of his case. In this scheme rights did not determine one's remedies, which logically should be the case and was, to a great extent, in the later Roman Law, in the time of the Jus Naturale, when profound changes had occurred in the strict law, under the influence of the praetor's edict and juristic writers. ${ }^{1}$ But at common law the remedies, historically at least, were the criteria of the rights. At common law, it was largely forgotten that the adjective or procedural law was merely a means of obtaining or securing one's substantive rights. Lawyers and judges, living in an age of scholasticism and legal maxims, made the law an end, and sought to make the law logically and mathematically a thing in itself. Record worship resulted, so far as pleadings were concerned, and when it was proposed finally to allow amendment of pleadings, Baron Parke exclaimed in opposition, "Think of the state of the record!" The harmful practise of trying the record and not the whole case, on appeal, was both a concomitant and a result of this view of the adjective law.

The manifest injustice under the older system of pleading requiring the pleader to abide by his particular theory, ${ }^{2}$ was only partially remedied by the device of amendment; for in the first

1 See Roscoe Pound, The Effect of Law as Developed in Legal Rules and Doctrines, 27 Harvard Law Review, 195 at p. 213 et seq.

2 "If a wrong action was adopted, the error was fatal to the whole proceeding, however clearly the facts of the controversy might have been brought before the proper court. The plaintiff may have served his adversary in due time, and ray have given as full information as to the material facts of the case as could be given in any other action; he may have proceeded openly and fairly in all matters; there may have been no question as to the substantial justice of his claim; but all this would not avail if his action was not technically the proper one. He must pay the costs and go out of court. If he chose, he could begin again, but under like conditions. At his peril he must select the appropriate formula. It was not enough that he stood within 
place, the judge on circuit, drawing his authority to try the case from the words of the original writ, issued by the chancellor, had no authority to allow amendments; and later, when these were permitted, the general rule was that they could and must not introduce a new cause of action. ${ }^{3}$

It is remarkable that the old common law rule of requiring a definite theory of the pleadings, should have obtained as long as it did, although it is partly explicable from the belief held by lawyers and judges generally that the common law was synonymous with natural and eternal law itself, which could not be changed; and partly, perhaps, from the natural conservatism of the law, coupled with the further fact of the characteristic dislike of innovation on the part of Englishmen. However, it is still

the temple of justice, he must have entered through a particular door. Or, to change the figure, chancery, the so-called officina justitiae, was like an armory. To it every man who would contend with another in the courts comes to choose his weapon. The choice is large. All the weapons of juridical warfare are here. But every weapon has its proper use, and can be put to no other. Moreover, only one weapon can be chosen at a time; and once chosen, it cannot be exchanged for a different weapon in the progress of the combat. If the fight is to go on, it must be with such a weapon as was first chosen, and according to its special rules. A sword being selected, the rules of sword play must be strictly followed. A crossbow may not be used as a mace. The issue of the combat must not be determined by brute force,-not even by the brute force of indisputable facts arrayed before the court. It is a contest of skill; success depends upon observing the formal rules of the combat." Hepburn, Development of Code Pleading, \$ 46; see also 50 L. R. A. (N. S.) 3, "Necessity of Theory of the Case in Pleading."

${ }^{3}$ De Graw v. Elmore (1872) 50 N. Y. 1; Steffy v. Carpenter (1860) 37 Penn. St. 41. A striking illustration of the rule, that the amendment must not introduce a new cause of action, is to be seen in the case of Allen $v$. Tuscarora Valley Ry. (1910) $229 \mathrm{~Pa}$. 97, 78 Atl. 34. Plaintiff, injured while a brakeman on the defendant railway, alleged in an action of trespass that the defendant had negligently adopted and used the pin and link coupler, more dangerous than the usual and ordinary coupling apparatus employed by railroads. Then he desired to amend his complaint and sue on a federal statute which made it a violation of law not to use couplers coupling automatically by impact. Prior to this federal act, employees of common ca iers assumed the risks and dangers naturally and ordinarily incident to the employment; but the federal statute relieved the employees from these. sks when the carrier was engaged in interstate commerce, and placed them upon carriers. The court denied the motion for amendment, on the ground that it created a new cause of action, taking away from the defendant the defense of assumption of risk. Hence, though the facts entitling plaintiff to recover were at all times the same, no relief was granted. Cases reaching similar results are Breen v. Iowa Central Ry. Co. (1918) 184 Ia. 1200, 168 N. W. 901 (amendment refused which would be barred by the Statute of Limitations); Carpenter v. Central Vermont Ry. Co. (1919) 107 Atl. 569 (Vt.) (semble); Baltimore \& O. R. R. Co. v. Branson (1917) 104 Atl. 356 (Md.).

Happily, a more liberal view app?ars to be gaining in some jurisdictions, illustrated in the following cases: Friederichsen v. Renard (1917) 247 U. S. 207, 62 L. Ed. 1074, 38 Sup. Ct. Rep. 450; Nash v. Minneapolis, etc., R. R. Co. (1918) 141 Minn. 148, 169 N. W. 540. On the whole matter, see Austin W. Scott, The Progress of the Law-Civil Procedure, 33 Harvard Law Review, 242. 
more remarkable that today, with sweeping changes being and having been effected in pleading, by the various codes and practise acts, adjective law as well as substantive law should still be regarded as something ideal, unchangeable, and eternal. As in the Mirror of Justices, ${ }^{4}$ the author complains of the more rational innovations for settling disputes, instead of the older method of trial by battle, so today one hears echos of high praise of the older forms of pleading. ${ }^{5}$ Many judges, trained in the belief that the system in which they have been trained is equivalent to natural law and reason itself, look upon changes made in the rules of pleading as beyond legislative competence-a good example of the two views of law dominant in this country, the Historical and the Analytical; the one denying the efficacy of effort to change the law as it has been inherited, the other tending to believe that the law may be made by the mere legislative fiat, of "be it enacted." While there is undoubtedly truth in both views, neither exclusively contains all of it. But this glorification of the old system is not merely confined to the bench; members of the bar also revere certain phases of the older system of requiring a definite theory of the pleadings. ${ }^{6}$

*Chap. V. $\S 1$, No. 19: "It is an abuse that justices drive a lawful man to put himself upon his country when he offers to defend himself against an approver by his body." No. 126: "It is an abuse that there is no trial by battle in personal actions as there is in case of felony."

5 Cf. McFaul v. Ramsey (1857) 61 U. S. (20 How.) 523, 525, 15 L. Ed. 1010: "This system, matured by the wisdom of ages, founded on principles of truth and sound reason, has been ruthlessly abolished in many of our states, who have rashly substituted in its place the suggestions of sciolists, who invent new codes and systems of pleading to order. But this attempt to abolish all species, and establish a single genus, is bound to be beyond the power of legislative omnipotence. They cannot compel the human mind to distinguish between things that differ. The distinction between the different forms of actions for different wrongs, requiring different remedies, lies in the nature of things; it is absolutely inseparable from the correct administration of justice in common law courts." See to the same effect the language in Supervisors v. Decker (1872) 30 Wis. 624; Chicago, St. L. \& P. R. Co. v. Bills (1885) 104 Ind. 13,3 N. E. 611.

${ }^{6}$ Mr. D'Arcy, writing in 1910 in 70 Central Law Journal, 405, said: "It is to be observed, too, that some of our leaders of the bar are doing their best to eliminate pleadings, and substitute the Turkish method of transferring property. Some of our tribunals have succeeded in getting away from the 'technicalities' of pleadings, and have substituted the method of pleading for recovery of a horse and allowing the pleader to recover on his 'theory of the case' that what he really wants is not a horse, but a cow." To this it might be said that under the old system of pleading, requiring a definite theory of pleadings, not even a "cow" was given the party with a valid cause of action because he had improperly diagnosed his case-a flagrant injustice, indeed. 


\section{The Advent of the Codes of Procedure.}

With the inauguration of the procedural reform activities of David Dudley Field in New York, in 1846, it was hoped by many law reformers that a new era had been reached in the adjective law. Codes, following the ideas of Field, were soon to be found in many of the states. But the courts, interpreting the provisions of the codes as merely declaratory of the common law, and that the legislatures could not really change the "fundamental and eternal" differences between the various causes of actions, disappointed the hopes of the codifiers. The case of Barnes v. Quig$\mathrm{ley}^{7}$ is illustrative of this tendency of the courts. The plaintiff, endorsee of a promissory note made by the defendant, in his declaration alleged that defendant had fraudulently represented to plaintiff that he had given the note to the payees solely for their accommodation. The answer was a general denial. It was proved that the defendant was not fraudulent, but that he had not made the note by way of accommodation; therefore, the trial court taking a more liberal view, struck out the allegations of fraud and permitted recovery in assumpsit. But this decision was reversed by the upper court, the opinion stating, what has since become the customary method of dealing with such cases in states where a requirement of the theory of the pleadings obtains:

"The complaint is for fraud and not upon contract. Whether the facts constitute a cause of action is not material. The whole framework is in fraud ... and it was an entire change of that cause and a surprise upon the defendant when this view was ignored by a counsel and court at the trial.... The two forms of action might require a very different defense."

Without pausing here to comment upon the merits of this decision, it is sufficient to point out that this case clearly lays down a definite "theory of the pleadings," which afterwards greatly influenced courts in other jurisdictions.

Codes based on the original New York code of procedure, have now been passed in a large number of states. ${ }^{8}$ Our problem is,

7 (1874) 59 N. Y. 265.

8 Arizona, Arkansas, California, Colorado, Connecticut, Idaho (Constitution), Indiana, Iowa, Kansas, Kentucky, Minnesota, Missouri, Montana (Constitution), Nebraska, Nevada, North Carolina, North Dakota, Ohio, Oklahoma, Oregon, South Carolina, South Dakota, Utah, Washington, Wisconsin, Wyoming. Generally, it may be said that these codes of procedure contain, with reference to the abolition of forms of actions, the following common provision: "The distinction between actions at law and suits in equity, and the forms of all such actions and suits, have been abolished, 
from an inductive study of the reports of decisions in code states, (1) To ascertain what jurisdictions follow the less liberal construction of the provisions of the codes with reference to abolition of causes of actions; (2) What states once having followed it have since abandoned it; (3) What states never in any definite way followed the illiberal view of the pleadings; and lastly, (4) To submit a critique of the "theory of the pleadings" doctrine itself.

\section{Where a Theory of the Pleadings is Reguired.}

The courts of New York have consistently followed the Barnes v. Quigley principle of requiring a definite theory of the pleadings, on which the complainant must try his case. In the fairly recent case of Jackson v. Strong, an accounting was brought alleging the existence of a partnership. But the proof being insufficient, recovery was denied, even though the referee found the defendant liable for a certain amount, defendant admitting he had agreed to pay plaintiff a reasonable value for his services. ${ }^{10}$

On the other hand, in the Appellate Division of the New York Supreme Court, a more liberal opinion has been expressed with reference to the theory of the pleadings. In Connor v. Philo ${ }^{11}$ the complaint alleged breach of a contract of employment. Defendant as principal contractor and employer was to receive a certain compensation from the owner, and from the proceeds pay the plaintiff. Plaintiff alleged, besides breach of contract, fraudulent

and there is in this state but one form of action for the enforcement or protection of private rights and the redress or prevention of private wrongs, which is denominated a civil action." Laws of Wisconsin, 1898, $\$ 4286$.

9 (1917) 222 N. Y. 149,118 N. E. 512.

10 So also Deyo v. Hudson (1919) 226 N. Y. 685, 123 N. E. 851. Where the proceedings should have been in equity, recovery at law will be refused. Reubens v. Joel (1853) $13 \mathrm{~N}$. Y. 488; Voorhis v. Child (1858) 17 N. Y. 354. And in De Graw v. Elmore (1872) 50 N. Y. 1, recovery was denied where the complaint was in tort and a cause of action proved on contract. The dissent by Mr. Justice Peckham takes the more liberal view. What effect the new Practice Act in New York may have, is too conjectural to be treated of here.

In Jackson v. Strong, supra, n. 9, the court in its opinion illustrates the tendency of the courts, prevalent at that time, to regard the common law adjective law as part of the jural order of nature itself. In part the opinion stated: "The inherent and fundamental differences between actions at law and suits in equity cannot be ignored. As has been said, pleadings and a distinct issue are essential to every system of jurisprudence, and there can be no orderly administration of justice without them. If a party can allege one cause of action and then recover upon another, his complaint would serve no useful purpose." This view, that the law in which one has been trained and educated, is synonymous with universal and natural law, has been one of the obstacles toward procedural reform.

11 (1907) 117 App. Div. (N. Y.) 349, 102 N. Y. Supp. 427. 
conversion of the funds by defendant. Although the plaintiff failed to prove the allegations of fraudulent conversion, the Appellate Division permitted recovery on the contract, treating the matters unproved as surplusage. So in Graham v. Graham ${ }^{12}$ the Appellate Division permitted recovery for repairs in a case predicated upon specific performance, which was impossible because of the statute of frauds.

Massachusetts ${ }^{13}$ appcars to follow the requirements of a theory of the pleadings, as is shown by two recent cases. In Ash v. Childs Dining Hall Company, ${ }^{14}$ an action of tort was brought alleging that the plaintiff had been injured by swallowing a tack in a piece of blueberry pie, which she had eaten in defendant's dining-hall, and that the defendant had been negligent, which defendant denied. It was shown that the tack was very small and might easily be overlooked, and no negligence on the part of defendant was proved. The Supreme Judicial Court held it error not to have directed a verdict for the defendant; because the plaintiff having adopted the theory of negligence, must abide by it, even though, as the court intimates, there might be a good cause of action on a contract implied between the parties. And in fact, in a case ${ }^{15}$ decided by the same court on the very same day as the Ash case, recovery was permitted on practically a sinilar state of facts, but where plaintiff had sued on an implied warranty instead. ${ }^{18}$ It will be noted that in the Ash case, the mere fact that plaintiff had made and failed to substantiate the allegations of negligence, prevented recovery, even though facts had been alleged and proved on which recovery should have been allowed; while in the Friend case, plaintiff omitted the allegations of negligence and on similar facts was granted recovery.

The courts of Indiana present, perhaps, the most striking

12 (1909) 134 App. Div. (N. Y.) 777, 119 N. Y. Supp. 1013.

13 Massachusetts, of course, is not strictly a code state, but all forms of action have been abolished except Contract, Tort, and Replevin. Rev. Laws, Ch. $173, \S 1$.

14 (1918) 231 Mass. 86, 120 N. E. 396.

15 Friend v. Childs Dining Hall Co. (1918) 231 Mass. 65, 120 N. E. 407.

16 In the Friend case, supra, the court said: "On principle and authority, it seems to us that the liability of the proprietor of an eating house to his guest for serving bad food rests on an implied term of the contract and does not sound exclusively in tort, although of course he may be held for negligence if that is proved. But in view of the fact that in Massachusetts the form of action to recover on an implied warranty may be tort or contract (Farrell v. Manhattan Market Co. (1908) 198 Mass. 271, 84 N. E. 481, $126 \mathrm{Am}$. St. Rep. 436), the inconsistent results reached in the two dininghall cases above, are all the more remarkable-but another example of the requirements of a theory of the pleadings. 
example of the doctrine requiring a definite theory of the pleadings. In Oolitic Stone Company v. Ridge ${ }^{17}$ the latter brought an action to recover damages for personal injuries sustained by him while in the employ of the Stone Company. The theory adopted by the court and the parties was that this action was governed by sub-division 2 of section 1 of the Employers' Liability Act. ${ }^{18}$ The Stone Company contended that the Act was unconstitutional, in violation of the Fourteenth Amendment to the Federal Constitution. Ridge claimed that his declaration stated a good cause of action not only under the Act, but also at common law, and that even if the Act were held to be unconstitutional, this should not deny him recovery. The lower court permitted plaintiff to recover on the view that the Act was constitutional, but pending appeal by the Stone Company the upper court declared the Act unconstitutional. When, therefore, the Stone Company was given its hearing before the higher court, a reversal in its favor was granted. ${ }^{19}$ The reason given for the decision, besides the necessity of requiring a definite theory of the pleadings, was that it would be unjust to the adverse party and also to the court to permit a party to assume a definite theory in the trial court and shift from it to another in the appellate tribunal.

The earlier case of Mescall v. Tully ${ }^{20}$ had applied the doctrine of a definite theory of the pleadings even to suits in equity. There the court said that the theory upon which the complaint was drawn was that a parol agreement transformed the deed from an absolute conveyance into an instrument creating a trust, and as this theory was overthrown by the authorities, the entire complaint was without foundation. ${ }^{21}$ Also in the case of Neidefer v. Chas$\operatorname{tain}^{22}$ a plea of fraud having not been proved, was denied, even

17 (1908) 169 Ind. 639,83 N. E. (Ind.) 246.

18 Acts of Indiana, 1893, ch. 130 , p. 234.

19 The court said: "It is an established rule of pleading that a complaint must proceed upon some definite theory and on that theory plaintiff must succeed or not succeed at all. As the theory adopted in the trial court was that this action was brought under... the Employers' Liability Act of 1893, that theory must be adhered to in the cause on appeal. As said Act is unconstitutional, so far as it applies to appellant, it follows the court below erred in overruling appellant's demurrer to the amended complaint." This is another example of injustice resulting from requiring a theory of the pleadings.

20 (1883) 91 Ind. 96.

${ }_{21}^{21}$ The result would be that if one sued in equity on the theory of specific performance, but showed facts creating a trust, he would be demed relief and would have to begin his suit de novo.

22 (1880) 71 Ind. 363, 36 Am. Rep. 198. 
though other facts were alleged and proved showing that the articles sued for by plaintiff were worthless. ${ }^{23}$

The courts of Missouri, requiring a theory of the pleadings, also warrant separate consideration. In Rush v. Brown ${ }^{24}$ the facts were such that relief could have been given either at law or in equity, but plaintiff having treated his suit as one for specific performance, had failed to substantiate the necessary elements under such a theory. The question was suggested whether the court might treat it as an action at law, which the court held could not be done. ${ }^{25}$

In Nave v. Dieckman ${ }^{26}$ the complaint alleged that the plaintiff had been a tenant on defendant's farm, and it had been agreed that should any disputes arise, growing out of the tenancy, these should be left to arbitration. In a dispute arising concerning the number of acres of land cleared by the plaintiff, the arbitrators found that the plaintiff had kept and performed his obligations, and that as a result defendant owed plaintiff $\$ 110$ for his services. At the trial, defendant denied the validity of this award, contending that he owed plaintiff only $\$ 60$, inasmuch as not all the work had been completed by plaintiff. The trial court, therefore, ignored the arbitration and award as a basis for recovery, and instructed the jury that, if they should find the defendant had agreed to pay plaintiff for clearing land and plaintiff had actually cleared some land, they should find for plaintiff for whatever sum was due. The upper court held this instruction to be erroneous, because not founded on the theory advanced by the parties. ${ }^{27}$

${ }^{23}$ So also Tibbet v. Zurbuch (1899) 22 Ind. App. 354, 52 N. E. 815 . In this case, the court itself ventured a guess as to the theory meant to be set forth, and tried the case to see whether the theory had been correct or not. See also the following cases requiring the theory of the pleadings: Cleveland Ry. v. Dugan (1897) 18 Ind. App. 435, 48 N. E. 238; Dyer v. Woods (1906) 166 Ind. 44, 76 N. E. 624; Terre Haute, etc. Ry. v. McCorkle (1895) 140 Ind. 613,40 N. E. 62 ; Aetna, etc. Co. v. Hildebrand (1894) 137 Ind. 462,37 N. E. 136, $45 \mathrm{Am}$. St. Rep. 194n. The requirement of a definite theory of the pleadings, on which plaintiff fails or succeeds, is apparently well settled in Indiana.

24 (1890) 101 Mo. 586, 14 S. W. 735.

25 In Rush v. Brown, supra, n. 24 , the opimion stated: "It would be a departure from the true spirit of the Code to require of plaintiff ' $a$ plain and concise statement of the facts constituting his cause of action,' without requiring (at some stage of the case) a plain statement of the judicial action demanded thereon, for the information of the defendant and of the court." The court here appears to be confusing the theory of the case with the theory of the pleadings-against the former, no objection can be made.

26 (1919) 208 S. W. 273 (Mo.).

${ }^{27}$ In its opinion, the court said in part: "Plaintiff was allowed to recover ... on the original contract without reference to the arbitration and award $\therefore$. The cause of action intended to be presented and tried was founded 
As to courts in other states which require a definite theory of the pleadings, separate, intensive treatment of the cases is not possible, either because these are in confusion or because appropriate cases are not obtainable. Only brief mention can, therefore, be made of those states.

In the courts of Nebraska there are dicta which apparently approve the doctrine of the theory of the pleadings. In Omaha Electric Light \& Power Company v. Butke ${ }^{28}$ the action was to recover damages because of certain excavations made by the defendant in "wrongfully and negligently" removing the supports which adjoined a conduit owned by plaintiff, running lengthwise along an alleyway. Plaintiff requested the court to charge the jury that a landowner had no -right to go upon a public street or alley to make excavations for the purpose of erecting a building upon his own property, and that he should be liable for damages caused upon the surface or beneath the surface of the street. Defendants contended that such instruction should be refused, as it would permit a recovery for a trespass in the alley, on a theory based on negligence. But plaintiff maintained that his petition stated a cause of action for both negligence and trespass. This the court denied and refused plaintiff recovery, saying that masmuch as plaintiff had adopted a theory of negligence, he could not recover for trespass.

The Minnesota courts clearly follow the Indiana courts in requiring the theory of the pleadings. In Sorenson v. School District $^{29}$ a suit was brought, by two resident voters and taxpayers, to enjoin the officers of the school district from abandon-

on and to enforce the arbitration and award. So too, the plaintiff tried his case on this theory, putting the arbitration and award in evidence and showing his compliance therewith and no more. . . . It is elementary that plaintiff cannot sue and try his case on one cause of action and recover on another. Even if on the trial of one cause of action, the evidence shows that the plaintiff might recover on another and different cause, he cannot be allowed to do so in that case, either with or without amending his complaint." This extract from the opinion illustrates well the medieval view of idealizing the record, to the expense of justice.

See to similar effect Huston y. Tyler (1897) 140 Mo. 252, 36 S. W. 654; International Co. v. Smith (1885) $17 \mathrm{Mo}$. App. 264; Schneider v. Railroad (1882) 75 Mo. 295; Waldhier v. Railroad (1880) 71 Mo. 514.

28 The court in its opinion said: "The language copied from the petition imports the theory of negligence. The mere use of the world "wrongfully, in absence of alleged facts constituting trespass, does not imply a cause of action based on that theory. If plaintiff intended to require defendants to answer for excavating in the alley in violation of law, the facts constituting trespass, as distinguished from negligence, should have been pleaded in the petition."

29 (1913) 122 Minn. 59, 141 N. W. 1105. 
ing a certain school-house site and the school established upon it, from erecting a new school-house upon another section of the township, and from issuing bonds therefor. Plaintiffs stated in their complaint that the proceedings for the selection of the new site had been abortive and had resulted, therefore, in a failure to make a proper selection; but they made no suggestion that another site than that claimed by the defendants to have been chosen was in fact selected. The defense was that 27 voted for and 24 against the site, and verdict was consequently ordered for the defendants. Thereupon plaintiffs desired to amend their complaint, to show that another site than that voted for, had been chosen, but this was refused by the court, it saying that a complaint must proceed upon a distinct and definite theory, and that this had been done in this case, and therefore plaintiffs must lose since they had not established it. Practically identical language with that of Indiana court opinions is used in the opinion in the Minnesota case. $^{30}$

Summarizing, it may be said that the theory of the pleadings is required, in some fashion at least, in the following states: New York, Massachusetts, Missouri, Indiana, Nebraska, Minnesota, South Dakota, Kentucky, and New Mexico. The general principles of the theory, code provisions to the contrary, may be stated as follows:

1. Where the action is based upon fraud, though other facts are alleged and proved entitling the complainant to recover, if the fraud is not proved, no recovery will be granted.

2. Where the suit was in equity, when it should have been at law, or vice versa, likewise no recovery will be permitted, even though sufficient facts appear which in justice and equity entitle the complainant to relief.

${ }^{30}$ The requirement of a theory of the pleadings prevails in the following states, as appears from cases cited:

South Dakota-Jones v. Winsor (1908) 22 S. D. 480, 118 N. W. 716. In an action for conversion, plaintiff's request to have his omission of allegations of ownership treated as surplusage and the action maintained as one for money had and received, was refused; the court quoting extensively from Indiana courts holding to a theory of the pleadings.

Kentucky-Smith v. Robinson (1919) $185 \mathrm{Ky}$. 76, 214 S. W. 771. Action on an express contract not proved, but court said action should be dismissed even though an implied one had.been proved.

New Mexico-Gallegos v. Sandoval (1910) 15 N. M. 216, 106 Pac. 373. Action of trespass against sheriff for abusive use of process maintained on a finding that the sheriff was oppressive, although not shown as was necessary under the statute, that sheriff had writ in his possession more than sixty days before levy. Court also quotes from Indiana opinions as to theory of pleadings. 
3. Where the action is ex contractu and facts are proved instead, which should warrant recovery ex delicto, no recovery is permitted. The converse is also true.

4. If the suit is on an express contract, and only an implied one is proved, no recovery will be granted.

5. The usual reasons given for requiring a definite theory are that (1) It would be a surprise to the defendant to permit recovery on another ground; (2) It would fail in tendering a definite issue or issues if no theory were adopted, and would lead to uncertainty and confusion; (3) The court itself would be in ignorance of the nature of the controversy if the plaintiff did not elect some definite theory of the pleadings. ${ }^{31}$

\section{States Which Have Abandoned the Requirements of a Theory of the Pleadings. 32}

The courts of Wisconsin once rigidly held to the doctrine of a definite theory of the pleadings being required. In the earlier case of. Supervisors v. Decker ${ }^{33}$ this requirement was stated in positive language. There the action was for embezzlement of public funds, but it was not clear from the complaint whether it was for trover or for money had and received. Plaintiff asserted that if the action could not be sustained as one for trover, it should be for money had and received, treating as surplusage the allegations and averments of fraudulent representations and fraudulently withholding money from plaintiff. To this position the court strongly reacted; as follows:

"We have often held that the inherent and essential differences and peculiar properties of actions have not been destroyed, and from their very nature cannot be. . . It cannot be 'fish, flesh, or fowl,' according to the appetite of the attorney preparing the dish set before the court."

$31 \mathrm{Cf}$. the dissent of Mr. Justice Peckham in De Graw v. Elmore, supra, n. 3: "The merits of the cause have been fully tried, without surprise to either party ... The defendant understood the complaint: there can be no pretense that he was misled by it. This variance between the pleadings and the proof the court had full authority to amend or to disregard under the Code."

For criticism of the view that abolition of pleadings would result in uncertainty and confusion, see Dean Pound "Some Principles of Procedural Reform," 4 Illinois Law Review, 388, 491, at pages 494-97. See also Clarke B. Whittier, "Notice Pleadings," 31 Harvard Law Review, 501.

${ }^{32}$ Distinction is made between those states which once followed the theory and later abandoned it, and those states which never followed it to any considerable extent.

${ }_{33}$ (1872) 30 Wis. 624. This case greatly influenced later cases in other states, as Indiana, Missouri, New York, etc., which held the doctrine of the theory of the pleadings, the case being quoted freely. 
But beginning in 1909, a succession of Wisconsin cases $^{34}$ completely abandoned the doctrine of Supervisors v. Decker, and decidedly different language was used as to the "inherent and essential differences and peculiar properties of actions." In one of these cases, that of Bieri v. Fonger, the court recognizes the more liberal spirit in interpreting codes of procedure, and attributes this partly to "the progressive tendency to broaden the judicial vision."

An equally noticeable instance of abandoning the requirement of a theory of the pleadings, after once having given it a trial, is to be seen in the courts of the State of Kansas. In Grentner v. Fehrenschield $^{35}$ the Kansas Supreme Court, in very emphatic terms, laid down the requirement of the theory of the pleadings, quoting freely from the Indiana decisions. In that case, the complainant Fehrenschield was joint owner with one Gruntges of certain real estate, which was exchanged for other property of another party, the exchange being negotiated by the nephew of Gruntges. After this had been done, plaintiff feeling he had not received a just share, brought this action, alleging fraud on the part of the nephew, and praying that both he and Gruntges be held as trustees for plaintiff's interest. The trial court found plaintiff had not received an equitable share, although no fraud was proved, and plaintiff was permitted to recover. But this decision was reversed by the Supreme Court, holding in accordance with the Indiana decisions, which it quoted, that plaintiff not having proved his specific theory, was not entitled to recover.

34 Bieri v. Fonger (1909) 139 Wis. 150,120 N. W. 862 ; Bannen v. Kindling (1910) 142 Wis. 613,126 N. W. 5, and Bruheim v. Stratton (1911) 145 Wis. 271,129 N. W. 1092.

In the first case, an action for assault and battery, plaintiff's allegations that defendant unlawfully entered upon her land and solicited criminal conversation were treated as surplusage.

The Bannen case was one for specific performance of an agreement changing a partnership into a corporation in which plaintiff should be admitted, but had been excluded. Though specific performance was not granted, the bill was retained on other grounds and relief given.

The last case involved trespass to lands in Minnesota and cutting down and appropriating timber to defendant's use. On suit being brought in Wisconsin, defendant's contention that this was a local action failed, the court treating the averments of trespass to land as surplusage, and allowing recovery on the allegations of conversion of the timber. This case virtually overruled Dessert L. Co. v. Wadleigh (1899) 103 Wis. 318, referred to in Bieri v. Fonger, supra, and the language in that case was very emphatic, as follows: "It is just as necessary today as it ever was that a suitor should so state his cause of action that the court may determine whether it be ex contractu or ex delicto ... The plan of "hitting it if it is a deer, and missing it if it is a calf, does not prevail in legal proceedings."

35 (1902) 64 Kans. 764, 68 Pac. 619. 
But in Cockerell v. Henderson ${ }^{36}$ a complete change of front was made by the Kansas Supreme Court. In that case the appellant brought an action to recover back the purchase price paid for certain corporate oil stock which was alleged to be worthless. The complaint averred that defendants were fraudulent in representing that ten to twenty-five barrels of oil were produced daily, and that the company owned a $\$ 19,000$ leasehold. A verdict was directed for defendants on their demurrer, but this was reversed by the Supreme Court on the ground that it was immaterial whether plaintiff's action was based upon the theory of fraud and deceit, or upon contract. Part of the opinion is pertinent with reference to which theory was intended:

"This discussion and controversy seem quite irrelevant, the only proper consideration being whether the petition states facts constituting a cause of action and whether the evidence was sufficient to justify the submission of the case to the consideration of the jury."

The courts of California have likewise abandoned, to some extent at least, their former decisions which adopted the theory of the pleadings. ${ }^{38}$ A clear statement of the more liberal view in

36 (1909) 81 Kans. 335, 105 Pac. 443.

37 In answer to the criticism, made in 8 Michigan Law Review, 315-317, that the Cockerell case, supra, n. 36, violates the common law distinction between actions ex contractu and ex delicto, it may be said that at common law no such distinction existed in reality, but was at most only a convenient classification.

${ }_{38}$ Two early cases decided by the California court appear at first sight to lay down the requirement of a theory of the pleadings. These two cases are Hayes v. Fine (1891) 91 Cal. 391, 27 Pac. 772, and Buena Vista Fruit \& Vineyard Co. v. Tuohy (1895) 107 Cal. 243, 40 Pac. 386. In the first case, the complaint alleged the existence of an express agreement between plaintiffs and defendants by which the former were to do certain labor on an irrigation ditch, in return for which defendants would become tenants in common in the ditch and the water rights. Plaintiffs not being able to prove the express agreement, because of the Statute of Frauds, then attempted to show that they had become such tenants merely by assisting in the labor of enlarging the ditch. This contention or theory the court refused to adopt, saying it was inconsistent with plaintiffs' complaint; that having relied on the purchase theory they could not, on failure to prove it, adopt some other theory when the facts in the complaint did not warrant it. In the second case mentioned above, the plaintiff corporation alleged that it had been defrauded by the defendants in giving notes for $\$ 62,000$ and cash of $\$ 10,000$ for land which was actually worth only $\$ 36,000$; it therefore asked to have the notes canceled, as well as a deficiency judgment and a foreclosure decree set aside. As plaintiff did not volunteer to return the land, the court was at a loss to know what theory plaintiff was suing on, saying that a party defrauded might rescind and restore within a reasonable time all of the value which he had received, or he might affirm it and sue for the damages. Here the plaintiff did neither, but while keeping the property was suing to have the notes canceled and judgment and decree set aside. The court in denying plaintiff relief, used this language: "Every complaint in an action should be 
construing the pleadings, to give any relief the facts might warrant, appears in the case of Rogers v. Duhart. ${ }^{39}$ The complaint alleged that plaintiff was tenant of a certain uninclosed ranch, and that defendant had pastured large herds of cattle and sheep on the land, damaging plaintiff to a considerable sum. It was shown in evidence that plaintiff was not in possession of the ranch at the time the alleged trespass was committed. The briefs of respective counsel were devoted, chiefly, to a discussion of the question whether. an action trespass quare clausum fregit could be maintained by one who was not in the actual possession of the land at the time the acts complained of occurred. The court said it would be useless to try to reconcile the cases, as it was immaterial whether the facts alleged showed an action trespass quare clausum fregit, trespass vi et armis, or any other technical form of action, ex delicto or ex contractu. The mere fact plaintiff in this particular case alleged he was not in possession was likewise unimportant, as such averments would be treated as surplusage if there were other facts present entitling him to relief. The court in part said:

"The rigid formalism and subtle distinctions found in the rules governing the common law forms of action are as inapplicable and inane under the modern plan of procedure as the highly dramatic speech, senseless repetitions, and symbolic gestures of the formulae prescribed by the five forms of civil actions by the decemvirs of Ancient Rome."40

founded upon a theory under which plaintiff is entitled to recover and should state all of the facts essential to support such theory. Failing in these respects, it is radically defective and does not state facts sufficient to constitute a cause of action." This appears to be a clear statement of a requirement of the theory of the pleadings, but as pointed out above, examination of the facts fails to reveal any ground for recovery whatsoever; so that the case is not inconsistent with later cases adopting a more liberal rule.

39 (1893) 97 Cal. 500, 32 Pac. 570.

40 The reference is likely to the procedure under the Legis Actiones. The five actions of per Sacramentum, pignoris capionem, manus injecto, postulationem, and condictionem were equally full of pitfalls for the litigant as the common law actions of trespass quare clausum fregit, trespass vi et armis, de bonis asportatis, trover, assumpsit, etc. Because of these defects, the legis actiones later gave way to the Formulary and Libellary procedures, just as the old common law actions were abolished by the codes of procedure. But as in the Roman Law, so in the Common Law, judges still thought in terms of the older procedure. On the whole matter, see Dean Roscoe Pound, "Readings in the Roman $L$ aw and the Civil Law and the Modern Codes," and Roscoe Pound, "The End of Law Developed in Rules and Doctrines," 27 Harvard Law Review, 195.

So also in Bell v. Bank of California (1908) 153 Cal. 234, 94 Pac. 889, the court expressly repudiated any requirement of a theory of the pleadings. Plaintiff sued to compel defendant to account for certain shares of stock deposited as pledgee. She made no tender for the stock, but repudiated the 
In the case of Bartley v. Fraser, ${ }^{41}$ the District Court of Appeal, First District, adopts a liberal view of the pleadings of the plaintiff, based entirely upon the statement of facts in the complaint. There the plaintiff alleged the making of a written contract by which defendant Fraser was to transfer to plaintiff an undivided one-half interest in certain mining claims in Mariposa county, payments to be made in installments, when the deed, which was to be left in escrow with the defendant City and County Bank of San Francisco, would be delivered. Plaintiff later, after going into possession, claimed to have ascertained that Fraser had "salted" the mine, and therefore asked that Fraser and the bank be made to return the contract entered into. The California Constitution, Article 6, Section 35, and the Code of Civil Procedure, Sections 392, 396, provided that real actions must be tried where the land lies, and that personal or transitory actions should be brought at the place where the defendant resided. The court, after deciding that the bank was not a necessary party to the suit, tried in vain to ascertain on what. particular theory plaintiff had brought his action, apparently being willing to regard it either as one involving land or a personal action against the defendant Fraser. It found, however, that whatever view it might take of the complaint on the basis of the facts alleged, that plaintiff must bring his action in Mariposa county, where defendant resided and where the land lay.

It must be borne in mind that the principle requiring a theory of the pleadings is not the same where the parties themselves have adopted a definite theory on the trial of the cause. Here on appeal no other theory should be permitted. Several California cases involve this point. In Tognazzini v. Freeman ${ }^{42}$ the complaint was for wilful and wanton negligence on the part of defendant in operating his automobile whereby plaintiff was damaged. A new trial was granted on the ground that the instruction of the trial judge was based on the theory of negligence, the court stating, however, that if the parties and the court had adopted a particular theory, whether of intentional wrong or negligent

pledge transaction, claiming defendant had no right to the stock whatever. Defendant had already disposed of the stock, and demurred on ground that, if the action were treated as one for conversion the statute of limitations had already run. While the demurrer was sustained, the court stated that no matter on what theory a complaint were framed, if it alleged facts which entitled one to relief on some other theory, this would be given.

41 (1911) 16 Cal. App. 560, 117 Pac. 683.

42 (1912) 18 Cal. App. 459, 123 Pac. 540. 
wrong, they would be bound by it on appeal. So also in Gervaise v. Brookins, ${ }^{43}$ in an action of ejectment, plaintiff alleged the rental value of the premises to amount to a certain sum, defendant's answer not adequately denying this allegation. Plaintiff appealed on the ground that a finding of a lesser value was contrary to the admissions contained in the pleadings; but the judgment was affirmed on the ground that the parties had tried the case on the theory that the value of the rents was in issue.44

Summarizing the situation which prevails in California with respect to the theory of the pleadings, it may be said that according to the Buena Vista Company case, ${ }^{45}$ "every complaint in an action should be founded upon a theory upon which the plaintiff is entitled to recover;" but to determine the theory, the facts alleged, and not the relief prayed for, will govern; and the mere fact that the complainant has alleged one theory, if his facts will warrant recovery on some other theory, will not be inaterial.4s And if the parties have accepted a certain theory in the trial court, they will not be permitted to urge a different theory on appeal. ${ }^{47}$ But these cases, where the parties themselves have decided on the theory on which the case is to be tried or argued, do not reach the real point concerning the theory of the pleadings. This is, if the facts state an apparent theory and one less apparent, and the first is unproved, whether the court will permit relief on the less apparent. The New York court in Ross v. Mather ${ }^{48}$ where the plaintiff alleged breach of a warranty and likewise alleged fraud, but failed to prove the latter, denied recovery on the ground that plaintiff had not made out his theory of the pleadings. The doctrine of the Tuohy case, ${ }^{49}$ as decided by the California case, would apparently require plaintiff to amend his pleading, rather than proceed on the less apparent theory.

South Carolina courts are gradually abandoning the illiberal inethod of interpreting the code changes as to causes of actions. In the earlier case of Proctor v. Southern Ry. ${ }^{50}$ the complaint in an action against the railroad company alleged that defendant

43 (1909) 156 Cal. 110, 103 Pac. 329.

44 See also Illinois Bank v. Pacific Ry. (1896) 115 Cal. 297, 47 Pac. 60.

45 Supra, n. 38.

4 Bartley v. Fraser, supra, n. 41; Bell v. Bank of California, supra, n. 40.

47 Tognazzini v. Freeman, supra, n. 42 ; Gervaise v. Brookins, supra, n. 43; Illinois Bank v. Pacific Ry., supra, n. 44.

48 (1872) 51 N. Y. 108, 10 Am. Rep. 562.

49 Buena Vista Fruit \& Vineyard Co. v. Tuohy, supra, n. 38.

${ }^{\circ 0}$ (1901) 61 S. C. 170,39 S. E. 351. 
"wilfully, wantonly, and recklessly," with intent to injure plaintiff, let off steam from its engine and blew the whistle, thereby frightening plaintiff's team at a crossing causing him damage. It was not proved that defendant had intentionally caused the injury, but the lower court instructed the jury that recovery might be allowed for negligence. This instruction was held erroneous by the upper court on the ground that the complaint, having charged an intentional injury, could not on that theory be maintained, after failure of proof, by proving a negligent wrong. ${ }^{51}$ It is difficult to understand, however, why the greater should not include the less, even in code pleading; and the later South Carolina case of Furman v. Tuxbury Land \& Timber Company, ${ }^{52}$ involving analogous circumstances, reached an opposite result from the Proctor case, in fact expressly overruling it. In the Furman case, the complaint was that Furman had "wilfully and in reckless disregard of plaintiff's rights," under a general license to cut timber, used certain steam skidders in removing timber from plaintiff's land. Defendant admitted using the skidders, but contended that under the terms of the license it was a "convenient method" of handling and removing timber, and on the trial this was proved. However, though plaintiff failed to prove defendant had acted wilfully and wantonly, as alleged, recovery was permitted by the court on the ground of negligence. ${ }^{53}$

The courts of Arkansas seem to have given up whatever part of the theory of the pleadings they once followed.54 In Crowder v. Fordyce Lumber $\mathrm{Co}^{55}$ plaintiffs brought an action to recover damages to a tract of land in cutting and removing timber there-

51 "While the system of code pleading is designed to obviate the asperities of some of the artificial and technical rules of the former system of pleading, we do not understand that it was intended to abrogate any of the fundamental rules based upon common right."

52 (1918) 112 S. C. 71,99 S. E. 111.

53 In the Furman case, supra, n. 52, the court after stating that the code required plaintiff only to state the facts of his cause of action, added: "It follows that the same state of facts may give rise to a cause of action for either negligence or wilfulness or indeed for both .... In either event, the injured party ought not to be required to determine at his peril the state of mind of the wrongdoer. If he charge the greater wrong, and prove only the lesser, the wrongdoer has suffered no prejudice; for if he come prepared to defend against the greater, he would be equally prepared to defend against the lesser." This sound rule only follows a similar rule in criminal procedure.

See also Birt v. Southern Ry. (1910) 87 S. C. 239, 69 S. E. 233.

$54 \mathrm{Cf}$. Jones v. Minogue (1874) 29 Ark. 637, 648, holding to the theory at least in equity, with the later case of Pindall $v$. Trevor (1875) 30 Ark. 249,260 , rejecting it in equity.

55 (1910) 93 Ark. 392, 125 S. W. 417. 
from. They alleged that they were the owners of the land in reversion, after the expiration of a widow's dower or life interest. Defendant, contending that this was an action of trespass to land, argued that plaintiffs could not maintain the action, for the reason that the complaint showed on its face that plaintiffs were not in possession. In answer to this the court said that under the Civil Code of Practice, where forms of action were abolished, all that was necessary was to state facts sufficient to constitute a cause of action within the jurisdiction of the court; adding that, while it was true under the common law procedure one must be in possession of land to recover in trespass, nevertheless in the case at bar the complaint could be construed as one to recover damages sustained to the reversionary interest, which at common law might have to be sued for in an action on the case. The general tenor of this opinion appears to favor a more liberal view of construing the code with reference to a theory of the pleadings.

In brief, it may therefore be said, that the foregoing courts, because of the widening of the "judicial vision," or because of stressing the pragmatic or practical considerations rather than the theoretical, as to code pleading, have recognized that their former well-meant illiberality has not been in harmony with the better and increasingly more liberal view. In some of these jurisdictions, the change to the liberal standpoint has been more marked than others, but in general, it may be said, the progress has been forward.

\section{States Taking a Liberal View From the BEGINNING., ${ }^{\text {sB }}$}

Inasmuch as the courts in these states take simply an opposite view of the general requirements of a cause of action from the courts of states which hold the theory of the pleadings, only brief mention need be made of them-sufficient to point out that the direful results, predicted by contrary-minded courts, sure to follow from abandoning the theory, have not occurred. In Knapp v. Walker $^{57}$ we find the Connecticut Supreme Court permitting recovery on contract, though the cause of action was based on fraud, thus agreeing with Mr. Justice Peckham's dissent in De Graw v.

56 These states, with the introduction of codes abolishing forms of actions, took generally a more liberal view, in harmony with the spirit of the reformed procedure itself.

57 (1900) 73 Conn. 459,47 Atl. 655. 
Elmore. ${ }^{58}$ So also in Cole v. Jerman ${ }^{59}$ the same court gave liberal construction to a pleading asking for the recovery of certain land, although if the action liad been treated as one in ejectment, as it would have been under a more illiberal view, plaintiff would have been defeated. ${ }^{60}$ And in the case of Grimes v. Greenblatt ${ }^{61}$ the Colorado Supreme Court permitted recovery for false imprisonment besides malicious prosecution, although the action was labeled the latter, the court stating that the code of procedure required only a concise and plain statement of the facts, without unnecessary repetition. And in Brown v. Baldwin ${ }^{62}$ the highest court of Washington permitted an action to quiet title even though defendants were in possession of the land, recognizing that at common law plaintiff would have been nonsuited and compelled to pursue his action at law in ejectment. Even though the proceeding was equitable in its nature, the court said if it became necessary in the trial of the cause to determine a purely legal right, the court, as it had always done, would call a jury to try out that question..$^{63}$ In Black v. Minneapolis \& Northern Elevator Company $^{64}$ the Supreme Court of North Dakota stated that though an action for conversion would not lie to recover for a seed lien on certain 'wheat because the plaintiff had no possession at the time, yet the action would be retained on the theory of a special injury to his lien rights if adequate proof appeared. The court recognized $^{\circ}$ the distinction between abolishing the differences as to remedies under code pleading, and yet preserving the rights under the substantive law. ${ }^{65}$. So in the case of Ricks v. Brooks ${ }^{66}$ the

58 (1872) 50 N. Y. 1.

59 (1904) 77 Conn. 374, 59. Atl. 425.

60 In accord: Morehouse v. Throckmorton (1899) 72 Conn. 449, 44 Atl. 747; Dunnett v. Thornton (1900) 73 Conn. 1, 16, 46 Atl. 168.

61 (1910) 47 Colo. 495, 107 Pac. 1111.

62 (1907) 46 Wash. 106, 89 Pac. 483.

${ }^{63} \mathrm{Cf}$. the New York case of Jackson v. Strong, supra, n. 9, where it was held that, if a jury trial was necessary, the equitable action must be dismissed and plaintiff pursue his remedy at law. In Browder v. Phinney (1902) 30 Wash. 74, 70 Pac. 264, relief for wrongful and forcible eviction was granted on an unacknowledged lease, where the lessee had taken possession and the lessor had accepted rent for two months, even though under the old system of procedure an action of law could not have been brought, but only a stuit in equity. See also Williams v. Snow (1920) 109 Wash. 329, 186 Pac. 861.

64.(1897) 7 N. D. 195,73 N. W. 90.

65 Accord: Miller v. National Elevator Co. (1915) 155 N. W. 871 (N. Dak.). In Lehman v. Coulter (1918) 40 N. D. 177, 168 N. W. 724, it was held error not to permit the defendant's request for a jury trial, where the action was to foreclose a chattel mortgage. From this it would seem that in North Dakota if the initial proceeding is equitable, and facts appear requiring decision by a jury, the plaintiff must proceed at law.

66 (1920) 179 N. C. 204,102 S. E. 207. 
Supreme Court of North Carolina ranged itself . with the more liberal states. In that case, if the action were to be treated as one for the correction of a certain deed or for its reformation, the weight of the evidence would necessarily have had to be greater; but if it were to be treated merely as a proceeding to set the instrument aside, less evidence would have been necessary. The court adopted the more liberal viewpoint consistent with the facts alleged and proved, stating pertinently:

"There is a wide difference between the statement of a defective cause of action; that is, when no cause of action is stated, and the defective statement of a cause of action. . . . Pleadings should be liberally construed for the purpose of determining their effect, and with a view to substantial justice between the parties." ${ }^{\text {B7 }}$

The courts of Nevada likewise follow the more liberal practice. A case showing this is Waters v. Stevenson. ${ }^{68}$ The complaint alleged that defendant wilfully and unlawfully entered upon the mines of plaintiff and extractcd therefrom and converted to his own use 640 tons of ore of the value of $\$ 16,000$. Defendant admitted the facts as alleged, but said he had entered through mistake. Consequently, the only question was with reference to the amount of damages plaintiff should recover, as it appeared that one Armstrong, as lessee of plaintiff before defendant's conversion, had re-assigned to the plaintiff after defendant's tortious entry. The court in delivering its opinion stated it was a matter of no practical consequence which theory was technically correct, as the result in any event must be in accordance with the facts alleged and proved. ${ }^{69}$

In brief, it may be said that besides the foregoing jurisdictions, the doctrine of the theory of the pleadings does not obtain in the

${ }^{67}$ Accord as to liberal view: Blackmore v. Winders (1907) 144 N. C. 212, 56 S. E. 874; Brewer v. Wynnd (1911) 154 N. C. 467, 70 S. E. 947 ; Muse v. Motor Co. (1918) 175 N. C. 466,95 S. E. 900.

68 (1878) 13 Nevada, 157.

${ }^{60}$ In the Waters case, supra, n. 68 , the court said: "Whether the pleader intended to allege trespass to the land, or trespass de bonis, or trover, the result is that the plaintiff is entitled to recover just such damages as are allowable from the facts alleged and proved which make up the whole case." 
following states: Oregon, ${ }^{70}$ Idaho, ${ }^{71}$ Oklahoma, ${ }^{72}$ Iowa, $^{73}$ Ohio, ${ }^{7 *}$ Montana, ${ }^{75}$ Arizona, ${ }^{76}$ and Wyoming. ${ }^{77}$

It may be safely asserted, therefore, that, including the states which have abandoned the requirement of a definite theory of the pleadings, the great weight of authority and the general tendency at present, is not to maintain such doctrine in code states; what the situation is in common law jurisdictions is beyond the scope of this paper.

\section{Summary and Conclusion.}

The doctrine of a theory of the pleadings, it is submitted, is open to several criticisms:

1. In the first place, courts which require the theory do not seem to grasp the distinction between actions and remedies. The legislatures, in drafting codes of procedure, did not intend to abolish the remedies then existing, but merely the actions or the machinery whereby the litigant was given his remedy. Under the old method, it was frequently the case that a suitor was disappointed because he brought an action at law and proved at the trial that he was entitled to an equitable remedy, and vice versa, or that he misconceived the nature or form of his action at law. It was undoubtedly the purpose of the legislatures to avoid such disappointments, involving expense and delay, by permitting a party to state the facts upon which he based his "primary right" and the acts or omissions violating that right, requiring the court to award the proper remedy. A similar practice obtained in the later Roman Law procedure, in the Libellary, where there was

70 (1919) 94 Ore. 292, 185 Pac. 746.

71 Bates v. Capital State Bank (19i0) 18 Idaho 429, 110 Pac. 277; Rauh v. Oliver (1904) 10 Idaho 3, 77 Pac. 20; Elliott v. Collins (1898) 6 Idaho 266, 55 Pac. 301 .

72 State National Bank v. Ladd (1917) 162 Pac. 684 (Okla.). In Byeson v. Territory (1909) 10 Okl. Cr. 677, 103 Pac. 532, a vigorous per curiam opinion stated that "justice demands that in the administration of law its processes should never be allowed to become a game of skill between contending counsel. There has been enough of this in the past. It has resulted in the miscarriage of justice in many cases and contempt for courts in the public mind."

${ }_{73}$ Hollenbeck v. Ristine (1898) 105 Iowa 488, 75 N. W. 355, 65 Am. St. Rep. 306.

${ }^{74}$ Gartner v. Corwine (1897) 57 Oh. St. 246, 48 N. E. 945.

${ }^{75}$ Cassidy v. Slemons \& Booth (1910) 41 Mont. 426, 109 Pac. 976; Haskins v. No. Pac. Ry. (1909) 39 Mont. 394, 102 Pac. 988; Raymond v. Blancgrass (1908) 36 Mont. 449, 93 Pac. 648.

${ }_{76}$ Sandoval v. Randolph (1908) 11 Ariz. 371.

77 Garber v. Spray (1917) 25 Wyo. 52, 164 Pac. 840, laying down rule in justice court, but tenor of opinion favors more liberal view generally. 
no general demurrer or general denial, but where it was the function of the court to determine the legal sufficiency of the pleadings presented. In other words, even with the introduction of codes of procedure, a wrong violating a primary right, whether one in rem or in personam, still gives rise to a secondary right, either legal or equitable, and entitles the party wronged to either a legal or an equitable remedy. What the legislatures did undertake to change or abolish was the distinction between the legal actions themselves and between them on the one hand and equitable proceedings on the other. But the remedies awarded by the courts were not to be affected, because the remedy is no part of the action or suit, but is the result of such action or suit.

2. Such a doctrine as the theory of the pleadings becomes more untenable when it is recalled that the codes generally provide that a complaint shall be demurrable when "it does not state facts sufficient to constitute a cause of action," while there is no provision that it shall be demurrable when it fails to proceed upon a definite theory.

3. Under the requirement of such theory, one must often bring and prosecute at the same time two cases on alternative theories of the same controversy. ${ }^{78}$ The inconvenience and expense of such practice need no comment.

4. The fear that harmful results would follow the abandoning of the requirement of a theory of the pleadings, has proved to be without foundation. Even though the basis of the action be fraud, with the allegation of other facts, and the fraud be unproved but recovery permitted by proof of the facts alleged, it cannot be said that the defendant has been surprised. As said by the dissenting opinion in De Graw v. Elmore, supra, the defendant undoubtedly understood the facts alleged, besides the fraud, and should have been upon his guard to make his defense in case the fraud was not proved.

5. The function of pleadings should be to give notice to the respective parties of the claims, defenses, and cross demands

78 See the cases of Murphy v. Brewing Co. (1908) 81 Neb. 223, $115 \mathrm{~N}$. W. 761 and Same v. Same (1908) 81 Neb. 219, 115 N. W. 763. Also the cases of Genau v. Abbott (1903) 68 Nebr. 117, 93 N. W. 942 and Genau v. Roderick (1903) 4 Nebr. Unoff. 436, $94 \dot{N}$. W. 523 . Cf. the sensible way in which the English Court of Appeals dealt with the theory of the pleadings in MacMillan \& Co. v. Dent [1907] 1 Ch. 107, 113. On the whole matter, see Dean Pound, "The Etiquette of Justice," 3 Nebr. St. Bar. Assn. (1908) 231. 
asserted by their adversaries, and the pleader should not be held to state all the legal elements of his claim. ${ }^{79}$

6. Where the initial proceeding was equitable, and it is later found some question must be determined by a jury, instead of dismissing the case and compelling the party to begin another suit, as would be required under the theory of the pleadings, a jury should be called to determine the point and the suit should be retamed. ${ }^{80}$

7. As to the contention that no recovery should be permitted ex contractu where the cause of action was treated as one ex delicto, it may be answered that at common law there was no such inherent distinction between actions, but only a mere conventional arrangement, which should not be maintained to deny recovery where the facts alleged are definitely proved, whether they savor of tort or contract. ${ }^{81}$

8. And with reference to the assertion that the theory of the pleadings leads to a definite issue and certainty in the trial of the cause, it may be answered that such is not always the case; for the general issue pleas and the common counts did not inform the court of the issue involved and extrinsic evidence was frequently necessary. Apparently no great hardship resulted, either with reference to the parties, the court, or the jury.

9. It is also difficult to understand why the greater should not include the less, in code pleading as well as elsewhere, so that where an express contract is declared upon and only an implied one is proved, recovery should be allowed.

In brief, those courts which have abandoned or rejected the theory of the pleadings, apparently have no difficulty administering justice equally as well as those courts which follow the theory. The courts following such a doctrine are still dominated by what Mr. Justice Holmes has so aptly termed "The inability of the 17th century common law to understand or accept a pleading that did not exclude every misinterpretation capable of occurring to an intelligence fired with a desire to pervert." ${ }^{\text {82 }}$ It is hoped that

79 Dean Pound, "Some principles of Procedural Reform," 4 Illinois Law Review, 497.

80 "If it becomes necessary in the trial of the cause to determine a purely legal right, the court, as it has always done, may call a jury to try out that question." Brown v. Baldwin, supra, n. 62 .

81 The only exception would be where the Statute of Limitations would be involved.

82 Paraiso v. United States (1907) 207 U. S. 368, 372, 52 L. Ed. 271, 28 Sup. Ct. Rep. 127. 
more judges will realize that the function of law is to serve as a means to an end and not an end in itself; and that so far as pleadings are concerned, record worship and the "etiquette of Justice" will be given up and the substantial rights of the parties emphasized.

E. F. Albertsworth

Dean, University of Wyoming Law School, Laramie, Wyoming. 